\title{
Obituary for an Agricultural Geographer - Soorya Lal Amatya, 1936 - 2017
}

Soorya Lal Amatya was born on March 3, 1936 at Kupandol, Lalitpur, Nepal. He died on February 4, 2017 at the age of 81. He did Master's Degree in Geography from M.S. University of Baroda, India in 1959 and also from University of Hawai, USA in 1964. He did his $\mathrm{PhD}$ from Banaras Hindu University, India in 1974. After his Master's degree from University of Baroda, he joined government of Nepal as section officer at the Ministry of Economic Planning for two years. In 1961, he joined Central Department of Geography, Tribhuvan University in 1961 as a Lecturer and promoted to

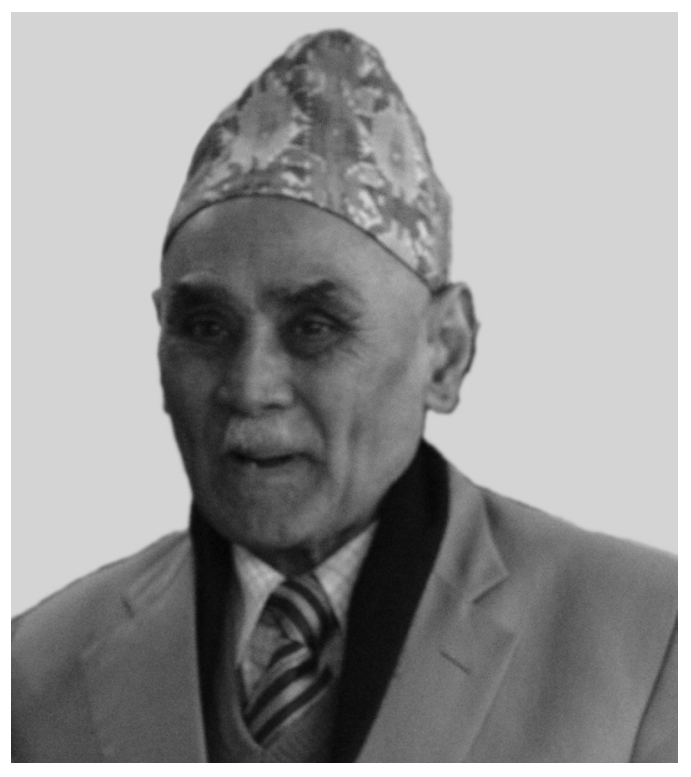
Professor in 1980. Late Prof. Amatya had multi-dimensional personality.

\section{A decent academic}

Late Prof. Amatya was one of the active and ebullient geographers and professors at the Central Department of Geography, TU, Kirtipur, Kathmandu, Nepal with over 37 years of teaching and research experience. He had more than 18 publications including articles in journals, books and newspaper articles with major focus on cash crops, urban and rural development, and decentralization. He attended and contributed several national level and international level seminars and conferences. He also served as Chief Editor of the Himalayan Review, the Journal of Nepal Geographical Society (1968-1974). He had more than 12 research projects. 


\section{A veteran academic administrator}

He had long experience of academic administration. He briefly served as Acting Head of Geography Instruction Committee, TU, Kirtipur (1971-1972). He had worked as Campus Chief, Kirtipur Campus, Tribhuvan University (1974-1975), National Programme Officer, UNICEF, Kathmandu ( 1976-1978), Deputy Director, Research Centre for Nepal and Asian Studies (CNAS), Tribhuvan University (1978-79), and Executive Director, Research Centre for Economic Development and Administration (CEDA), Tribhuvan University (1990-1993). After his retirement as Professor, he was appointed as Rector of Tribhuvan University in 2007 and served there for four years.

\section{A voluntary intellectual}

He was the president of many professional societies - Tribhuvan University Himalayan Club (since 1978), East-West Centre Association, Nepal Chapter (1988), Nepal Geographical Society (1974-1981), Nepal Council of World Affairs (1975-1977 and 1979-1981), Public Administration Association of Nepal. He was the Board Member of US Education Foundation, Nepal (1980-1982) and member of National Development Council, Government of Nepal (1992).

The Central Department of Geography has lost a prominent geographer who was very active in various fields of education, administration and research. The noteworthy memories of sincerity, frankness and friendliness he has left for us are unforgettable to follow. The department family members (CDG) extend their deepest condolence to his family. 